\title{
抑制性神経シナップスを標的とする殺虫活性物質の作用機構
}

\author{
田中啓司 \\ 三共株式会社農薬研究所
}

\section{Mode of Action of Insecticidal Compounds Acting at Inhibitory Synapse}

\author{
Keiji TANaka \\ Agricultural Chemicals Research Laboratories, Sankyo Co., Ltd., \\ Yasu-cho, Yasu-gun, Shiga 520-23, Japan
}

\begin{abstract}
All cyclodiene-resistant strains of the German cockroach, the house fly and the mosquito are also resistant to picrotoxinin, a well-known GABA antagonist. By using electrophysiological techniques, picrotoxinin was confirmed to act at a presynaptic region, resulting in a stimulation of the release of an excitatory transmitter. The electrophysiological symptoms caused by picrotoxinin were quite similar to those of $\gamma$-BHC and dieldrin. It was determined by using a ${ }^{3} \mathrm{H}$-dihydropicrotoxinin binding method that the nerve membrane in CNS of the American cockroach contained a component having a high affinity toward picrotoxinin and heptachlor epoxide, which can be regarded as a picrotoxinin receptor. By using a sucrose density centrifugation technique, it was determined that the fraction sedimented at the interphase of 1.0 and $1.2 \mathrm{~m}$ sucrose at $100,000 \times g$ contained the highest level of specific binding site. The ${ }^{3} \mathrm{H}$-dihydropicrotoxinin binding on the receptor was inhibited by all cyclodienes tested and $\gamma$-BHC. Toxaphene, bicyclic phosphate and TETS also bound with the receptor. Dieldrin resistant German cockroach showed cross-resistance to the chemicals having binding potencies to picrotoxinin receptor. Milbemycin and avermectin were found to stimulate $\mathrm{Cl}^{-}$uptake by the leg muscles of the American cockroach within $4 \mathrm{~min}$ at $10^{-7} \mathrm{M}$. This stimulatory action could be antagonized by picrotoxinin $\left(10^{-4} \mathrm{M}\right)$. It was concluded that the action of milbemycin ard avermectin is to open the chloride channel on the plasma membrane. Their actions do not seem to be mediated through GABA receptor, picrotoxinin receptor and benzodiazepam receptor, suggesting their direct attack on the chloride channel proper both in the central nervous and the neuromuscular systems.
\end{abstract}

\section{は じめに}

BHC や DDT 等が各種害虫に対し高い殺虫活性を有 することが発見されてから使用禁止になるまでの 20 年 以上もの間，世界各地でさかんに使用されてきた。 その 間，これら殺虫㓱が人類福祉に果たしてきた功績は大き く, 第 2 次世界大戦後の害虫防除による食糧増産や，風 土病，マラリヤ病等の原因となる衛生害虫の撲滅に貢献 してきた役割りを忘れてはならない。が，しかし，同時 に，これら殺虫剤の作用機構等について十分に，あるい はまったく知られていない状態で永年使用され，ついに
使用禁止になったという事実も忘れてはならない，いま は過去のものとなったこれら殺虫剤の作用機構を十分に 知ることは，今後の新農薬創製や，現在使用されている 殺虫戍のより深い理解につながると思われ，人類が将来 も化学物質で自然の一部を少しでもコントロールしょう とするかぎり，このような知見の蓄積はきわめて重要で ある。

昆虫と哺乳動物との間で高い選択性を有する殺虫郕を イメージに描く場合, まず両者の生理・生態の違いに着 目寸る. この点から, 神経系の違いも選択性のあるケミ カルコントロールー殺虫戍の大きなターゲットになる. 
$\gamma$-アミノ酪酸（ $\gamma$-aminobutyric acid: GABA）は，昆虫， 哺乳動物いずれにおいても抑制性の神経伝達物質として 機能しているが, 昆虫の場合, その重要度ははるかに高 く, この機能を摫乱する化合物は高い選択性を有する殺 虫剤になりえると古くから考えられてきた，しかし， GABA の関与する神経系についての理解は, acetylcholine の場合ほど進んでいない. Acetylcholine の場合, この系をターゲットとする有機リン系やカーバメート系 殺虫剤がすでに知られており，これらの化合物の作用機 構解明とともにその理解が深まってきた. しかし GABA の系の場合, 先の有機リン剂に相当する化合物はほとえ どなく，その点から GABA の系一すなわち抑制性神経 シナップスを標的とする殺虫剤の出現が待たれていた。 神経薬理の分野では, GABA の agonist として muscimol が, 一方, antagonist として picrotoxinin (PTX) と bicuculline が知られている。

本論文では, $\gamma$-BHC や cyclodiene が PTX と同様に一 GABA の antagonist として一作用している事実を，ま た, milbemycin や avermectin が GABA 様の一正確には GABA の agonist としてではない一作用をしている事実 を，どのように解明していったか，順次，簡単にではあ るが説明していく．詳しくは，オリジナルの報告を参照 されたい.なお筆者が本学会誌に解説としてまとめた “GABA 支配の神経シナップス”1) は，本論文を理解す るうえで手助けとなるであろう。

\section{$\gamma$-BHC と cyclodiene の作用機構}

\section{PTX との交差抵抗性}

本研究の端緒は, ミシガン州立大学 Matsumura 教授 グループにより, PTX が dieldrin 抵抗性のチャバネゴ キブリに対し交差抵抗性を示すことが明らかにされたこ
とから始まる2．これを受けて，筆者は， $\gamma$-BHC や dieldrin に対し抵抗性を示すイエバェ，力に，同様の PTX との交差抵抗性現象が認められるかどうか調べた ${ }^{3)}$. そ の結果が Table 1〜3 である. 古くから $\gamma$-BHC と dieldrin あるいは toxaphene との間に例外のない交差抵抗性 が知られていた4 6) が，上記昆虫でも同様に PTX との 交差抵抗性が認められた.この現象はチャバネゴキブリ だけに特異的なものでなく，広く種々の昆虫間に認めら れる普遍的なものとして，とらえてよさとうである。な おイエバェの CLD 系統は dieldrin 抵抗性であり，力の Isla Verde 系統も同様 dieldrin 抵抗性系統である. Rockefeller系統は DDT 抵抗性ではあるが dieldrin に対しては Trinidad系統同様感受性を示したことからDDTはPTX, $\gamma$-BHC, cyclodiene とは交差抵抗性を示さなかった。

\section{2. 電気生理}

Shankland $5^{7)}$ やUchida $5^{8)}$ は, dieldrin $p \gamma$-BHC が昆虫の中枢神経のシナップス前膜に作用し，アセチル コリンの異常放出を引き起こすとする説を提出してい る. いずれの研究も電気生理による観察にもとづいたも のである. 筆者は, 共同研究者の J. Scott の協力を得 て, PTX が $\gamma$-BHC や cyclodiene と同様に作用してい るかどうか, 電気生理学的手法によって確かめた ${ }^{9)}$.

Fig. 1 はPTXによる自発性放電であるが，そのパター ンは $\gamma$-BHC や dieldrin ときわめて類似していた. PTX がシナップス前膜に作用しているかどうかは, Shankland らの方法にならって確かめた。すなわち PTX の自 発性放電は, シナップス前膜からの神経伝達物質の放出 をさまたげる $\mathrm{Mg}^{2+}$ の存在により抑制された。また，ア セチルコリンの生合成阻害剤であるへミコリニウム -3 (HC-3) でも同様 PTXによる異常放電は抑制され，つ いにはまったく放電しなくなった。しかし，この時点で

Table 1 Susceptibility of dieldrin-resistant and dieldrin-susceptible German cockroaches to dieldrin, $\gamma$-BHC and picrotoxinin. ${ }^{2)}$

\begin{tabular}{lccc}
\hline Strain & $\begin{array}{c}\text { Dieldrina) } \\
\mathrm{LT}_{50}(\mathrm{hr})\end{array}$ & $\begin{array}{c}\gamma \text {-BHC } \\
\mathrm{LD}_{50}(\mu \mathrm{g} / \delta)\end{array}$ & $\begin{array}{c}\text { Picrotoxinin } \\
\mathrm{LD}_{50}(\mu \mathrm{g} / \hat{\delta})\end{array}$ \\
\hline CSMA & 6.4 & 0.23 & 0.11 \\
FRPP & 33.6 & 0.95 & 0.70 \\
LPP & 120.0 & 2.17 & 5.11
\end{tabular}

a) Surface contact method ( 2) 参照).<smiles>O=C1C(Cl)C2CC1C(Cl)C1(Cl)C(Cl)=C(Cl)C2C1(Cl)Cl</smiles>

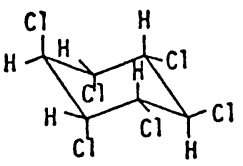

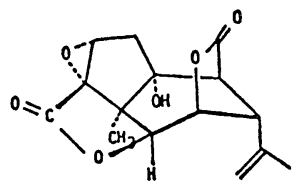


Table 2 Susceptibility of dieldrin-resistant and dieldrin-susceptible houseflies to dieldrin, $\gamma$-BHC and picrotoxinin.

\begin{tabular}{crrc}
\hline \multirow{2}{*}{ Strain } & \multicolumn{3}{c}{$\mathrm{LD}_{50}(\mathrm{ng} /$ 우 $)$} \\
\cline { 2 - 4 } & Dieldrin & $\gamma$-BHC & Picrotoxinin \\
\hline SBO & 12.9 & 3.9 & $22.6 \times 10^{3}$ \\
CLD & 254.0 & 22.4 & $\left.>50.0 \times 10^{3 \mathrm{a}}\right)$ \\
\hline
\end{tabular}

a) At $50 \mu \mathrm{g} /$ fly the actual mortality was $10 \%$.

Table 3 Susceptibility of three strains of Aedes aegypti larvae against picrotoxinin. ${ }^{\text {a) }}$

\begin{tabular}{|c|c|c|c|c|}
\hline \multirow{2}{*}{ Strain } & \multirow{2}{*}{$\begin{array}{l}\text { Picrotoxi- } \\
\text { nin } \\
(\mathrm{ppm})\end{array}$} & \multirow{2}{*}{$\begin{array}{l}\text { Piperonyl } \\
\text { butoxide } \\
(\mathrm{ppm})\end{array}$} & \multicolumn{2}{|c|}{$\mathrm{LT}_{50}(\mathrm{hr})$} \\
\hline & & & $\underset{1}{\text { Expt. }}$ & $\underset{2}{\text { Expt. }}$ \\
\hline Trinidad & 30 & 3 & 9 & 12.5 \\
\hline Rockefeller & 30 & 3 & 16 & 16.5 \\
\hline Isla Verde & 30 & 3 & $>48$ & $>48$ \\
\hline Isla Verde & 30 & 9 & 8 & 13 \\
\hline Isla Verde & - & 9 & 17.5 & 18 \\
\hline Isla Verde & 30 & 12 & 14.3 & 9 \\
\hline Isla Verde & - & 12 & 9 & 12 \\
\hline
\end{tabular}

a) Application method through sand coating.

も神経自体は nicotine に対し正常に反応したことから， シナップス後膜自体は正常であることが明らかとなり， PTX が $\gamma$-BHC や dieldrin 同様にシナップス前膜に作用 していることがわかった。

神経薬理学ではPTXが GABA の代表的な antagonist であること，そして哺乳動物に対し痤攣や興奮を誘起す ることが知られている ${ }^{10)}$. そこで，哺乳動物においてそ の存在が認められている GABA 受容体や PTX 受容体 が昆虫に存在するかどうか，さらに，存在するなら，そ の受容体の存在場所と受容体上で PTX と $\gamma$ - BHC p cyclodiene との拮抗がみられるかどうかがきわめて重要な 問題となる。これらの点について定性面および定量面で の解明のためのアプローチを試みた。 GABA 受容体の 存在はあとでふれるとして，まず PTX 受容体について 論を進める。

\section{PTX 受容体}

PTX 受容体に対する放射性リガントとして ${ }^{3} \mathrm{H}$-dihydropicrotoxinin ( ${ }^{3} \mathrm{H}$-DHPTX) を用いた。 DHPTX は PTX の isopropenyl 基の二重結合を還元したもので自身 PTX より生理活性は少し劣るが，しかし依然高い活性 を保持している10).
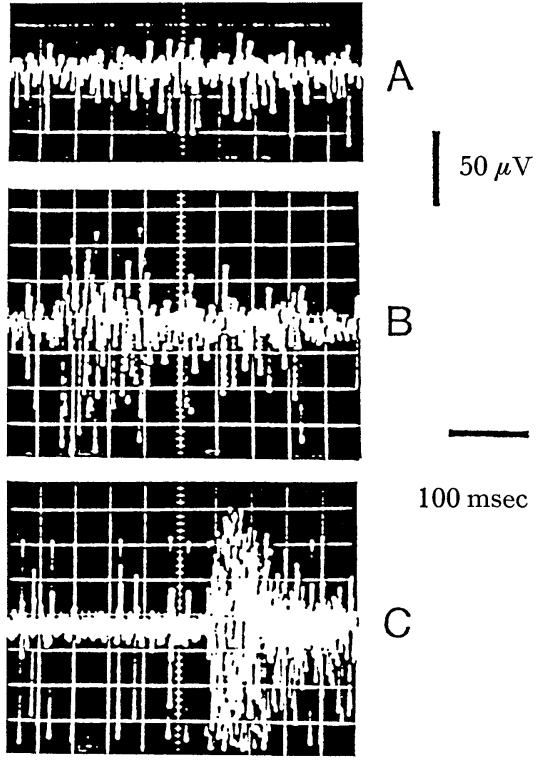

$100 \mathrm{msec}$

C

Fig. 1 Picrotoxinin poisoning symptoms in the isolated abdominal nerve cord of $P$. americana (A) before treatment, and (B) 40 and (C) $60 \mathrm{~min}$ after treatment at $10^{-5} \mathrm{M}$.

供試昆虫としてはワモンゴキブリ，チャバネゴキブリ を用いて，それらの神経膜フラクションを調製した。 た同様の方法によりイエバェ，カからも神経膜フラク ションを調製した. 粗に調製したフラクション $\left(\mathrm{P}_{2}+\mathrm{P}_{3}\right)$ に PTX 受容体が存在するかどうか調べた結果が Fig. 2 である. ワモンゴキブリの脳 (A. brain) と前胸および腹 部中枢神経節 (B. nerve cord) いずれにも, 低濃度の PTX で置換され，しかも $10^{-5} \mathrm{M}$ 近辺の濃度で飽和する，き わめて PTXに高い親和性を示すフラクション (PTX 受 容体）が存在することが明らかとなった．次いで，この 粗 $\mathrm{P}_{2}+\mathrm{P}_{3}$ フラクションのどの部分に PTX受容体が局在 するかについて調べた。 $\mathrm{P}_{2}+\mathrm{P}_{3}$ フラクションをショ糖 密度勾配遠心分離法によって細かく分画した結果, Table 4 に示したとおりショ糖濃度 $1.0 \sim 1.2 \mathrm{M}$ に分画される 部分に，もっとも多く PTX 受容体は存在していた.こ の $1.0 \sim 1.2 \mathrm{M}$ に分画される部分には, シナプトゾーム と呼ばれるシナップス膜由来の小胞体が存在しており， PTX の作用部位が $\gamma$-BHC や cyclodiene 同様シナップス 前膜であるとする先の電気生理実験結果と一致する。

次に，この PTX 受容体に対して $\gamma$-BHC や dieldrin が高い親和性を有しているかどうかが重要なポイントと なる。そこで heptachlor epoxideを用いて以下の実験 を行なった， $\gamma$-BHCや dieldrin のかわりに heptachlor 

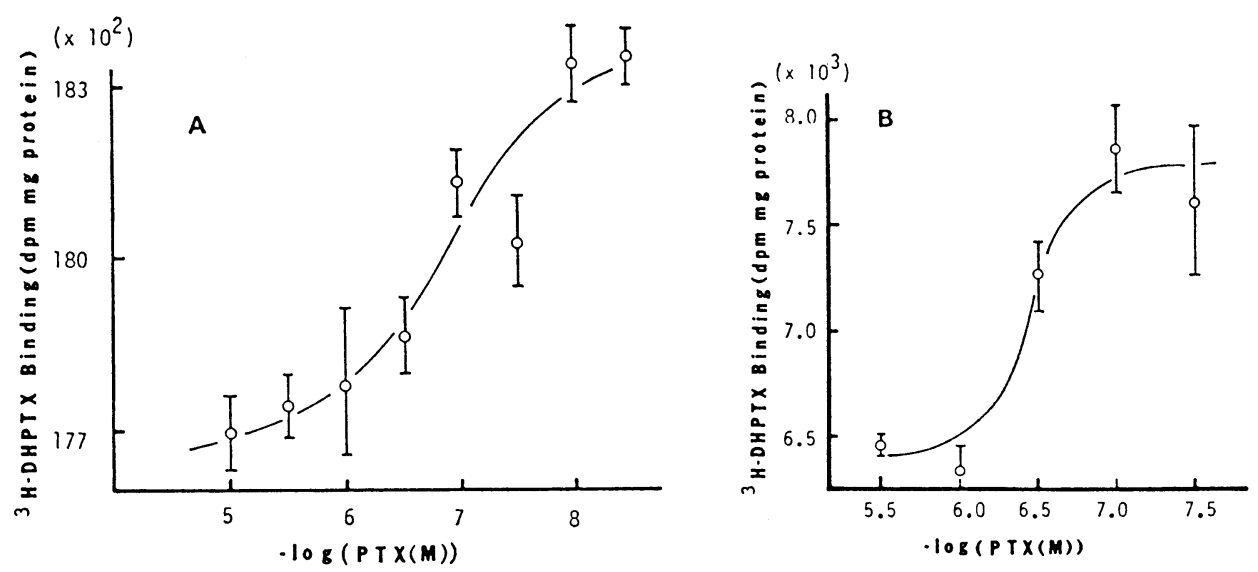

Fig. 2 Competitive inhibition of $\left[{ }^{3} \mathrm{H}\right] \alpha$-dihydropicrotoxinin (DHPTX) binding to nerve components of $P$. americana by picrotoxinin.

The concentration of $\left[{ }^{3} \mathrm{H}\right]$-DHPTX used in the experiments was (A) brain, $11.1 \mathrm{~nm}$; (B) nerve cord, $8.4 \mathrm{~nm}$. Data are expressed as means \pm S.E. of three determinations (dpm/mg protein).

Table 4 Subcellular localization of $\left[{ }^{3} \mathrm{H}\right] \alpha$-dihydropicrotoxinin binding in American cockroach head.

\begin{tabular}{ccc}
\hline \multirow{2}{*}{$\begin{array}{c}\text { Sucrose density } \\
\text { gradient fraction } \\
\left.(\mathrm{M})^{\mathrm{a}}\right)\end{array}$} & \multicolumn{2}{c}{$(\mathrm{dpm} / \mathrm{mg} \text { protein })^{\mathrm{b}, \mathrm{d})}$} \\
\cline { 2 - 3 } & \multicolumn{1}{c}{ Total } & Specific \\
\hline 0.8 & $13,777 \pm 104$ & $720 \pm 186$ \\
$0.8-1.0$ & $15,862 \pm 359$ & $720 \pm 102$ \\
$1.0-1.2$ & $16,688 \pm 104$ & $1783 \pm 66$ \\
$1.2-1.5$ & $12,344 \pm 45$ & $605 \pm 10$ \\
$1.5-1.8$ & $10,072 \pm 630$ & $553 \pm 417$ \\
1.8 & $11,970 \pm 1061$ & $\left.-{ }^{\mathrm{c}}\right)$ \\
\hline
\end{tabular}

a) Fraction $0.8(\mathrm{M})$, cell membrane; 0.8-1.0, large pieces of cell membrane and small pieces of nerve ending particles; 1.0-1.2, pinched off nerve endings (synaptic vesicles) and a few mitochondria; 1.2-1.5, nerve ending particles (more electron dense nature) and mitochondria; $1.5-1.8$, cell fragments and a few mitochondria; 1.8 , nonnural tissue.

b) $\left[{ }^{3} \mathrm{H}\right] \alpha$-Dihydropicrotoxinin (sp act, $30 \mathrm{Ci} /$ $\mathrm{mmol}), 11.1 \times 10^{-9} \mathrm{M}$.

c) Not tested.

d) Data are expressed as means \pm S.E. of two experiments, each experiment involving three determinations.

epoxide を用いたのは， $\gamma$-BHC や dieldrin に比べきわめ て代謝をうけにくく，乙れまで heptachlor epoxide の代 謝物がまったく知られていないからである，受容体ーリ
ガント結合実験と, in vivo (虫体) あるいは in vitro (神経レベル) でのそのリガントによる中毒症状とを，互 いに化学量論面から比較検討する際, heptachlor epoxide の場合には代謝物の関与を考慮に入れなくてすむからで ある. Fig. 3 に示したとおり heptachlor epoxide は ${ }^{3} \mathrm{H}$ DHPTX の PTX 受容体への結合を拮抗的に阻害した。 $\mathrm{IC}_{50}$ 值はほぼ $3 \times 10^{-7} \mathrm{M}$ 近辺であった. 次にこの結合実 験で PTX 受容体に結合していた heptachlor epoxide を 定量し, in vivoで heptachlor epoxideによる中毒症状を 呈しているワモンゴキブリの中枢神経中に見いだされる heptachlor epoxide の量とをとれぞれ定量・比較し, PTX 受容体への heptachlor epoxide の結合が実際の中毒症状 発現を説明できるレベルにあるかどうか, 化学量論面か ら検証した. ワモンゴキブリ雄成虫に $10^{-7} \mathrm{~mole} /$ ゴキブ リの heptachlor epoxide を腹部に施用すると, 室温下, 約 12 時間後に痤攣を伴った cyclodiene や $\gamma$-BHC 特有 の中毒症状を呈しはじめた．まさにその時に中枢神経を 注意深く取り出し，その神経中に存在する heptachlor epoxide を定量したところ, 中枢神経 (胸部と腹部) と脳 にはとれぞれ 94.4 と $36.7 \mathrm{ng} / \mathrm{mg}$ protein 存在してい た.この神経をさらにホモゲナイズし, ショ糖密度勾配 遠心分離法によって各分画に分け，ショ糖濃度 1.0 $1.2 \mathrm{M}$ に分画される神経膜小片に結合している heptachlor epoxide の定量を行なった (Table 5). In vivo で 中毒症状を呈しはじめたワモンゴキブリの中枢神経系一 とりわけシナップス前膜部分（1.0 1.2 M の分画）に結 合していた heptachlor epoxide の量は, 先の PTX 受容 

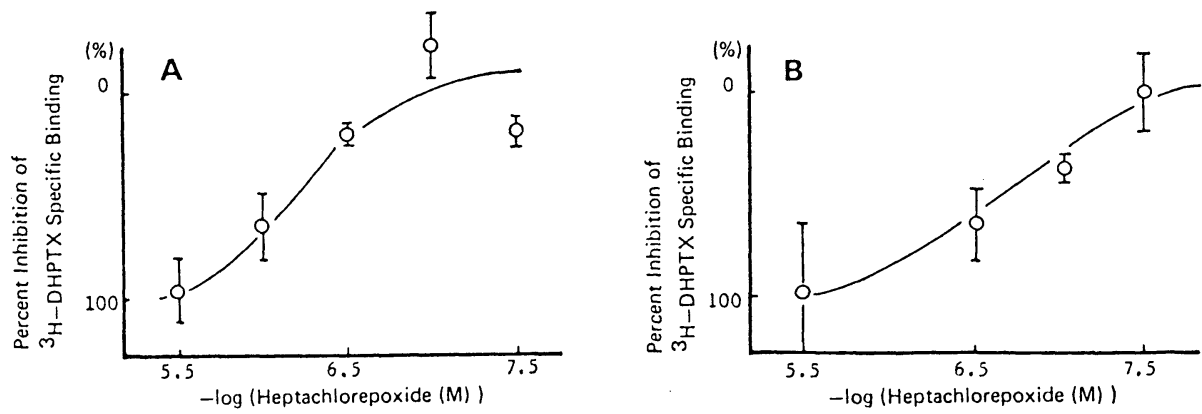

Fig. 3 Competitive inhibition of $\left[{ }^{3} \mathrm{H}\right] \alpha$-dihydropicrotoxinin (DHPTX) binding to nerve components from the brain of $P$. americana by heptachlor epoxide.

The concentration of $\left[{ }^{3} \mathrm{H}\right] \alpha$-DHPTX used in the experiment was $16.6 \mathrm{~nm}$. Data are expressed as means $\pm \mathrm{S}$.E. of three determinations.

Table 5 Subcellular localization of heptachlor epoxide in American cockroach central nervous system: comparison of heptachlor epoxide accumulation in vivo vs in vitro.

\begin{tabular}{|c|c|c|c|}
\hline \multirow{3}{*}{$\begin{array}{c}\text { Fraction } \\
\text { (Sucrose density) } \\
\text { gradient }(\mathrm{M}) \text { ) }\end{array}$} & \multicolumn{3}{|c|}{ Heptachlor epoxide recorded (ng/mg protein $)^{\text {a }}$ ) } \\
\hline & \multicolumn{2}{|c|}{ in vivo $\left.{ }^{\mathrm{b}}\right)$} & \multirow{2}{*}{$\frac{\left.\text { in vitro }^{\mathrm{c}}\right)}{\text { Brain }}$} \\
\hline & Central nerve cord & Brain & \\
\hline 0.8 & $81.2 \pm 29.4$ & $41.5 \pm 9.9$ & $200.3 \pm 30.9$ \\
\hline $0.8-1.0$ & $101.0 \pm 51.2$ & $53.7 \pm 21.8$ & $122.1 \pm 10.8^{\mathrm{d})}$ \\
\hline $1.0-1.2$ & $123.3 \pm 69.3$ & $56.9 \pm 17.1$ & \\
\hline $1.2-1.5$ & $66.0 \pm 24.3$ & $25.3 \pm 13.1$ & $107.3 \pm 20.8$ \\
\hline $1.5-1.8$ & $10.2 \pm 4.9$ & $5.1 \pm 5.8$ & $38.5 \pm 29.5$ \\
\hline 1.8 & $16.7 \pm 5.2$ & $8.2 \pm 5.3$ & $49.2 \pm 21.4$ \\
\hline
\end{tabular}

a) The determination of the level of heptachlor epoxide in-subcellular fraction was carried out by gas liquid chromatography after extraction by ether. Data are expressed as mean \pm S.E. of two experiments.

b) Heptachlor epoxide was topically applied on the abdomen: $1 \times 10^{-7}$ mole/roach. The insects which showed convulsions were immediately dissected. Their brains and central nerve cords were separately homogenized in $0.25 \mathrm{~m}$ sucrose. The homogenate was centrifuged at $1000 \times g$ for $10 \mathrm{~min}$. The supernatant was recentrifuged at $20,000 \times g$ for $45 \mathrm{~min}$. The pellets were disrupted with osmotic shock and then were centrifuged in a discontinuous sucrose gradient.

c) The crude mitochondrial fraction was incubated with heptachlor epoxide $\left(1 \times 10^{-6} \mathrm{M}\right)$ for 25 min at $0^{\circ} \mathrm{C}$. After centrifugation of this fraction, the pellet was disrupted and centrifuged as shown in b).

d) The data of fraction $0.8-1.2$.

体結合実験で， ${ }^{3} \mathrm{H}$-DHPTX の結合を 50\% 以上阻害して いた際の heptachlor epoxide の量とほぼ等しく, heptachlor epoxide の中毒症状が heptachlor epoxide の PTX 受容体への結合を経て起こっているとする考えを定量面 から支持した。なおラット脳シナプトゾームでの heptachlor epoxide による ${ }^{3} \mathrm{H}$-DHPTX の PTX 受容体結合阻 害の $\mathrm{IC}_{50}$ 值は $2 \times 10^{-6} \mathrm{M}$ とワモンゴキブリの場合より も高く,この違いは現に in vivo での heptachlor epoxide
の哺乳動物と昆虫に対する毒性に選択性があることから 興味深い.

他の cyclodiene や pyrethroid 等, 種々の殺虫剤によ る ${ }^{3} \mathrm{H}$-DHPTX の PTX 受容体への結合阻害程度を調べ た結果が Table 6 である. Cyclodiene はすべて ${ }^{3} \mathrm{H}$ DHPTXの結合を阻害した。しかも阻害の程度は, aldrin $<$ dieldrin $<$ photodieldrin, heptachlor $<$ heptachlor epoxide, isodrin<endrin といずれの場合とも epoxy 化されたもの 
のほうが高く，殺虫活性傾向と一致した． BHC の四つ の異性体 $(\alpha, \beta, \gamma, \delta)$ のうち $\gamma$-BHC にきわめて高い ${ }^{3} \mathrm{H}$ DHPTX 阻害活性が認められ，これも殺虫活性結果と一 致した。ただ殺虫活性のない $\delta$-BHCにも高い阻害活性 が認められている点についてはとの詳細は不明である

Table 6 Effect of cyclodienes and other agents on $\left[{ }^{3} \mathrm{H}\right] \alpha$-dihydropicrotoxinin binding. ${ }^{\text {a }}$

\begin{tabular}{|c|c|}
\hline Agents $^{b}$ ) & $\begin{array}{c}\text { Percentage inhibition of } \\
{\left[{ }^{3} \mathrm{H}\right] \alpha \text {-dihydropicrotoxinin }} \\
\text { specific binding }{ }^{c)}\end{array}$ \\
\hline Dihydropicrotoxinin & 100 \\
\hline Aldrin & $36.6 \pm 0.6$ \\
\hline Dieldrin & $58.5 \pm 2.3$ \\
\hline Photodieldrin & $79.0 \pm 4.3$ \\
\hline Heptachlor & $36.6 \pm 18.6$ \\
\hline Heptachlor epoxide & $57.3 \pm 31.3$ \\
\hline Isodrin & $35.6 \pm 3.8$ \\
\hline Endrin & $62.3 \pm 12.4$ \\
\hline$\gamma$-Chlordane & $56.2 \pm 2.0$ \\
\hline Oxychlordane & $77.8 \pm 6.2$ \\
\hline $\begin{array}{l}\text { Hexachlorocyclo- } \\
\text { pentadiene }\end{array}$ & $0.3 \pm 2.2$ \\
\hline Mirex & $14.7 \pm 15.7$ \\
\hline Kepone & $135.5 \pm 18.4$ \\
\hline Toxaphene & $72.3 \pm 28.1$ \\
\hline DDT & $5.4 \pm 3.6$ \\
\hline$\alpha-\mathrm{BHC}$ & $21.4 \pm 18.5$ \\
\hline$\beta$-BHC & $15.3 \pm 15.4$ \\
\hline$\gamma$-BHC (lindane) & $91.5 \pm 20.0$ \\
\hline$\delta$-BHC & $55.0 \pm 16.0$ \\
\hline Parathion & $4.1 \pm 26.3$ \\
\hline Allethrin & $13.2 \pm 6.7$ \\
\hline Cypermethrin & $7.7 \pm 3.1$ \\
\hline Decamethrin & $-0.1 \pm 1.0$ \\
\hline Fenvarelate & $-0.4 \pm 5.8$ \\
\hline Chlordimeform & $7.8 \pm 4.7$ \\
\hline Pentobarbital & $21.1 \pm 8.1$ \\
\hline Benzodiazepam & $45.1 \pm 10.8$ \\
\hline SQ-65396 & $21.5 \pm 5.7$ \\
\hline SQ-20009 & $-8.3 \pm 4.2$ \\
\hline $\begin{array}{l}\text { Tetramethylene- } \\
\text { disulfotetramine }\end{array}$ & $27.1 \pm 13.0$ \\
\hline $\begin{array}{l}t \text {-Butyl bicyclic } \\
\text { phosphate }\end{array}$ & $46.6 \pm 2.9$ \\
\hline
\end{tabular}

a) $\left[{ }^{3} \mathrm{H}\right] \alpha$-Dihydropicrotoxinin, $11.1 \mathrm{~nm}$; five American cockroach heads were used for one experiment (one agent), which involves three determinations.

b) Dihydropicrotoxinin, $100 \mu \mathrm{M}$; others, $10 \mu \mathrm{M}$.

c) Data are expressed as means \pm S.E. of two or three experiments, each experiment involving three determinations.
が， $\delta$-BHC に強い興奮抑制作用のあること ${ }^{11)}$ と関係が ありそうである．これは今後の問題であろう．ラット脳 シナプトゾームでの ${ }^{3} \mathrm{H}-\mathrm{DHPTX}$ 結合が，強い興奮抑制 作用のある barbiturate により阻害されることが知られ ている(2).

DDT, 有機リン剂, pyrethroid には ${ }^{3} \mathrm{H}-\mathrm{DHPTX} の$ 結 合に対する阻害活性は認められなかった。 Type II の pyrethroid が PTX 受容体と結合して，その作用を発現 しているとする説も提出されている13) が，少なくとも， ワモンゴキブリでは関係がなさそうである.

\section{4. 抵抗性メカニズム}

$\gamma$-BHC に対しても抵抗性を示す “第 3 夢の島”系イ エバェは，Table 7 に示すとおり高い代謝分解活性を有 していたが，同時にターゲット部位（神経系）での $\gamma$ BHC に対する感受性の低下も認められた ${ }^{14)}$.すなわち， 殺虫活性 ( $\mathrm{LD}_{50}$ 值) における大きな同位体効果は高い代 謝活性の存在を，また，中毒症状を呈しはじめた直後の 虫体内 $\gamma$-BHC- $d_{6}\left(\gamma\right.$-BHC より代謝されにくい $\left.{ }^{15)}\right)$ の量 の違いはターゲット部位での $\gamma$-BHC に対する感受性の

Table 7 Insecticidal activity and isotope effect on $\mathrm{LD}_{50}$ values of lindane and $\left[d_{6}\right]$-lindane.

\begin{tabular}{|c|c|c|c|}
\hline \multirow[b]{2}{*}{ Insecticide } & \multicolumn{2}{|c|}{$\left.\mathrm{LD}_{50^{\mathrm{a}}}{ }^{\mathrm{a}}\left(\times 10^{-10} \mathrm{~mol} / \mathrm{fly}^{\mathrm{b}}\right)\right)$} & \multirow[b]{2}{*}{$\begin{array}{l}\text { Ratio } \\
\text { (R/S) }\end{array}$} \\
\hline & $\mathrm{S}_{\text {NAIDM }}$ & $\begin{array}{l}\text { Third } \\
\text { Yumenoshima } \\
\text { (R) }\end{array}$ & \\
\hline Lindane & 6.53 & $>2200$ & $>337$ \\
\hline$\left[d_{6}\right]$-Lindane & 2.06 & 86.2 & 41.8 \\
\hline $\mathrm{H} / \mathrm{D}^{\mathrm{c})}$ & 3.17 & $>25$ & \\
\hline
\end{tabular}

a) Twenty-four-hour mortality after topical application. The standard error of the listed mean value was less than $15 \%$ of each value.

b) Four-day-old female adult.

c) $\mathrm{LD}_{50}($ lindane $) / \mathrm{LD}_{50}\left(\left[d_{6}\right]\right.$-lindane $)$.

Table 8 Effective amount of internal $\left[d_{6}\right]$ lindane producing convulsions on $50 \%$ of flies within $30 \mathrm{~min}$.

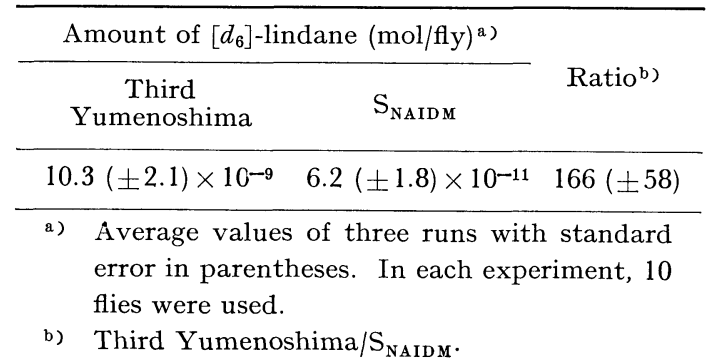


Table 9 Minutes to onset of poisoning symptoms: Abdominal nerve cord of susceptible and resistant German cockroach (B. germanica).

\begin{tabular}{rcc}
\hline \multirow{2}{*}{ Strain } & \multicolumn{3}{c}{ Minutes to onset of poisoning } \\
\cline { 2 - 3 } & $\begin{array}{c}\text { Dieldrin } \\
\left(10^{-5} \mathrm{M}\right)\end{array}$ & $\begin{array}{c}\text { Picrotoxinin } \\
\left(10^{-5} \mathrm{M}\right)\end{array}$ \\
\hline CSMA (S) & $53.8 \pm 5.5(5)$ & $61.8 \pm 11.5(4)$ \\
LPP (R) & $>91.8 \pm 12.8(5)>120.3 \pm 11.7(4)$ \\
\hline
\end{tabular}

Table 10 Time to onset of poisoning symptoms in the abdominal nerve cord of susceptible (CSMA) and resistant (LPP) German cockroaches: Dihydropicrotoxinin $\left(10^{-5} \mathrm{M}\right)$ with piperonyl butoxide $\left(10^{-4} \mathrm{M}\right)$.

\begin{tabular}{cc}
\hline Strain & $\begin{array}{c}\text { Minutes to onset of } \\
\text { poisoning symptoms }\end{array}$ \\
\hline CSMA & $26.5 \pm 3.7$ \\
LPP & $74.0 \pm 6.7$ \\
\hline
\end{tabular}

a) Data are expressed as means \pm S.E. of five experiments.

違いを示している (Table 8).

Dieldrin 抵抗性チャバネゴキブリの神経レベルターゲ ット部位での dieldrin に対する感受性の低下を電気生 理学的に直接証明したのが Table 9 である. 感受性と抵 抗性両系統の中枢神経を同一濃度の薬液に浸し，Fig. 1 に示したような自発性放電が観察されるまでの時間経過 を追うことにより，神経に取り込まれた薬物の量と抵抗 性との関係を明らかにしょうとしたもので，同一条件 下，同一レベルの症状を呈するのに，明らかに抵抗性の ほうが長時間を要した ${ }^{9) 。}{ }^{3} \mathrm{H}-\mathrm{DHPTX}$ を用いて同様の 実験を行なうとともに, 神経自体への放射能の取り込み も調べた (Table 10, Fig. 4) ${ }^{3)}$. 神経自体への放射能の取 り込みには，両系統間でほとんど差が認められなかっ た。したがって自発性放電があらわれた時点で両系統の 神経仅取り込まれていた放射能 ( $\left.{ }^{3} \mathrm{H}-\mathrm{DHPTX}\right)$ にはかな りの量的な違いが生じていたことになる．同一レベルの 症状を誘起するのに, 抵抗性系統の神経では多量の薬郕 が必要だったわけである.な括 $\gamma$-BHC- $d_{6}$ の $\mathrm{LD}_{50}$ 值に 怙ける同位体効果の大小を目安とした系統間の代謝能比 較実験で興味ある結果が得られた．Dieldrin で淘汰され た dieldrin 抵抗性チャバネブキブリは, 感受性系統とほ とんど代謝能が同じか, あるいは, 逆に抵抗性系統のほ うが低いという結果であり， dieldrin は酸化的代謝によ

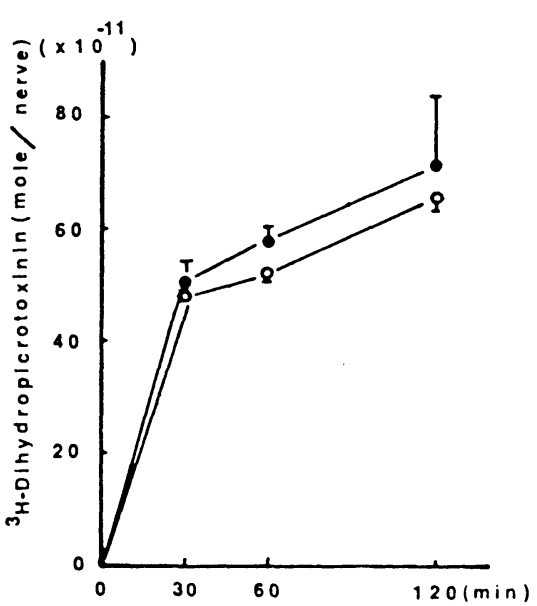

Fig. 4 Penetration of ${ }^{3} \mathrm{H}$-DHPTX into the abdominal nerve cords of the two German cockroach strains: dieldrin susceptible CSMA (-) and resistant LPP (O) strains.

Data are expressed as means \pm S.E. of four nerve cords.

ってほとんど解毒されず，逆に活性化される可能性のあ ることが示唆された.

電気生理学的に確認されたターゲット部位一神経一で の dieldrin に対する感受性の低下をPTX 受容体レベル でどうなっているか知らうとした ${ }^{3)}$.

抵抗性系統のチャバネゴキブリの中枢神経膜では, 感 受性系統に比べ, ${ }^{3} \mathrm{H}$-DHPTX の特異的結合部分 (specific binding）が少なく，その程度は Table 11 に示すとおり 抵抗性レベルと負に相関していた。一方，筋肉から調製 した神経膜では，そのような傾向は認められず，抵抗性 が中枢神経の PTX 受容体レベルでの現象であることも 明らかとなった，中枢神経膜での結合実験データを，さ らに詳しく解析するため Scatchard 分析したのが Fig. 5 である. PTX 受容体の数, 解離定数 $\left(K_{\mathrm{d}}\right)$ とも抵抗性 系統のほうが小さかった. 同様の現象は, イエバエ, カ の幼虫でも認められたことから，かなり普遍的な現象と みなすことができそうである，昆虫は PTX 受容体の質 と量をかえることによって， $\gamma$-BHC や cyclodiene に対 する抵抗性を獲得していったのである.

以上の研究結果をまとめると次のようになる.

1) $\gamma$-BHC, dieldrin, PTX が交差抵抗性を示した.

2) $\gamma$-BHC, dieldrin, PTX はシナップス前膜に作用し て, 特徵的な自発性放電 (Fig. 2) を引き起こした.

3）昆虫にはPTX 受容体が存在し， $\gamma$-BHC, cyclodiene, toxaphene 等はそれと特異的に結合した. 
Table 11 Comparison of specific $\left[{ }^{3} \mathrm{H}\right] \alpha$-dihydropicrotoxinin binding to head and body homogenates $^{a}$ ) from the susceptible and two resistant strains of German cockroaches in vitro.

\begin{tabular}{|c|c|c|c|c|}
\hline \multirow{3}{*}{ Strain } & \multicolumn{4}{|c|}{$\left[{ }^{3} \mathrm{H}\right] \alpha$-Dihydropicrotoxinin binding (dpm/mg protein) } \\
\hline & \multicolumn{2}{|c|}{ Head } & \multicolumn{2}{|c|}{ Muscles } \\
\hline & Total & Specific & Total & Specific \\
\hline CSMA & $46,157 \pm 2898$ & $6013 \pm 1670$ & $41,891 \pm 256$ & $1769 \pm 64$ \\
\hline FRPP & $47,328 \pm 1229$ & $4887 \pm 1006$ & $37,932 \pm 173$ & $3178 \pm 355$ \\
\hline LPP & $44,150 \pm 993$ & $1382 \pm 419$ & $44,008 \pm 1361$ & $2768 \pm 1340$ \\
\hline
\end{tabular}

a) The heads and the muscles (thorax and legs) from 100 male cockroaches per experiment were homogenized in $0.25 \mathrm{~m}$ sucrose and centrifuged at $800 \times g$ for $10 \mathrm{~min}$. The supernatant fraction was centrifuged at $20,000 \times g$ for $45 \mathrm{~min}$ and the pellets were resuspended in $0.2 \mathrm{M} \mathrm{NaCl}$ in $5 \mathrm{~mm}$ sodium phosphate buffer ( $\mathrm{pH} 7.0$ ) including piperonyl butoxide (final concentration: $10^{-5} \mathrm{M}$ for the head and $10^{-4} \mathrm{M}$ for the body experiment) for $\left[{ }^{3} \mathrm{H}\right] \alpha$-dihydropicrotoxinin binding assay (sp act $59.5 \mathrm{Ci} / \mathrm{mmol}, 1.65 \times 10^{-8} \mathrm{M}$ final concentration). Specific binding was defined as pelletable radioactivity $(20,000 \times g, 20 \mathrm{~min})$ which could be displaced by $0.1 \mathrm{~mm}$ of nonlabeled dihydropicrotoxinin. Data are expressed as means $\pm \mathrm{S}$.E. of two or three experiments, each experiment involving three determinations.

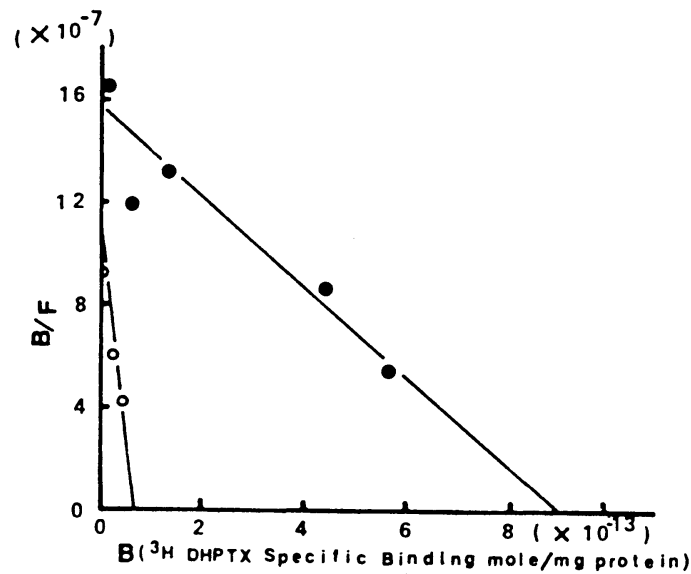

Fig. 5 Scatchard plot analysis of $\left[{ }^{3} \mathrm{H}\right]$-DHPTX binding to the brain membrane preparations from two German cockroach strains: dieldrin susceptible CSMA (๑) and resistant LPP (O) strains. $B_{\max }$ (receptor number) mole/mg protein was CSMA, $9.0 \times 10^{-3} ;$ SPP, $7.1 \times 10^{-14} ; K_{\mathrm{d}}$ (dissociation constant $(\mathrm{M}))$ was CSMA, $5.8 \times 10^{-7}$; LPP, $6.45 \times 10^{-8}$. Data are expressed as means of two independent experiments, each experiment involving three determinations.

4) $\gamma$-BHC p dieldrin 抵抗性昆虫はPTX 受容体の数 と質を変えることによってその抵抗性を獲得していた。

PTX が $\gamma$-BHC や cyclodiene とまったく同一の作用機 構を有していたのは驚きである，ただ，構造上に類似性
がないわけではない16).かりに 1)〜3）を同時に満たす 化合物が存在すれば，それは $\gamma$-BHC や cyclodiene と まったく同一の作用機構を有する一GABA antagonist, PTX agonist一化合物ということになる. Table 6, 12〜 14 を注意深くみると bicyclic phosphate, TETS 等はそ れに該当する.

\section{Milbemycin と avermectin の作用機構}

抑制性神経伝達物質 GABA の agonist 的な作用を有

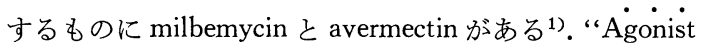
的”と断った理由としては次の 2 点がある. これらの化 合物が $\mathrm{GABA}$ 同様神経膜の $\mathrm{Cl}$ イオンのコンダクタン ス変化をもたらす点がその一つである17). もう一点は “的”のほうで GABA やその agonist である muscimol には, milbemycin や avermectin にみられるような高い 殺虫・殺ダニ活性 ${ }^{18,19)}$ はみられず, また, GABA の作 用は可逆であるのに対し，これらの化合物は不可逆的に 作用して Cl一 イオンのコンダクタンス変化を引き起こす ことから必ずしも GABA agonist と位置づけられぬから である。

Milbemycin や avermectin の GABA agonist 的な作用 一神経膜の $\mathrm{Cl}$-イオンの透過性を高める一がどのように して引き起こされているかについてワモンゴキブリの脚 部筋肉 (coxal muscle) を用いて調べた ${ }^{20)}$. この筋肉には 抑制性の神経が入り込えでいることが知られている ${ }^{21)}$.

1. ${ }^{36} \mathbf{C l}-$ 取り込み $\left({ }^{36} \mathrm{Cl}^{-}\right.$influx $)$実験 ${ }^{20,22)}$

顕微鏡下で解剖し, 取り出したワモンゴキブリの脚部 
Table 12 Comparative toxicities of cyclodiene insecticides to dieldrin susceptible (CSMA) and resistant (LPP) German cockroaches. ${ }^{\text {a) }}$

\begin{tabular}{|c|c|c|c|c|}
\hline \multirow{2}{*}{ Cyclodiens ${ }^{a}$ ) } & \multicolumn{2}{|c|}{$\left.\mathrm{LT}_{50}(\mathrm{hr})^{\mathrm{b}}\right)$} & \multirow{2}{*}{$\frac{\text { Resistance ratio }}{(\mathrm{LPP} / \mathrm{CSMA})}$} & \multirow{2}{*}{$\begin{array}{l}\left.\text { Dieldrin }{ }^{c}\right) \text { type } \\
\text { nerve excitation }\end{array}$} \\
\hline & CSMA strain & LPP strain & & \\
\hline Aldrin & $5.8 \pm 0.3$ & $51.1 \pm 5.4$ & $8.8 \pm 1.2$ & $t^{d)}$ \\
\hline Dieldrin & $11.6 \pm 0.9$ & $181.6 \pm 21.9$ & $15.7 \pm 2.2$ & + \\
\hline Photodieldrin & $11.1 \pm 0.5$ & $101.0 \pm 8.8$ & $9.1 \pm 0.9$ & + \\
\hline Heptachlor & $4.3 \pm 0.4$ & $57.5 \pm 7.8$ & $13.4 \pm 2.2$ & + \\
\hline Heptachlor epoxide & $7.0 \pm 0.2$ & $111.2 \pm 5.9$ & $15.9 \pm 1.0$ & + \\
\hline Isodrin & $9.1 \pm 0.3$ & $21.3 \pm 1.7$ & $2.3 \pm 0.2$ & + \\
\hline Endrin & $8.7 \pm 0.5$ & $16.3 \pm 1.3$ & $1.9 \pm 0.2$ & + \\
\hline$\alpha$-Chlordane & $14.3 \pm 2.1$ & $>192$ & $>13.4$ & + \\
\hline Oxychlordane & $5.3 \pm 2.1$ & $60.5 \pm 5.4$ & $11.4 \pm 1.1$ & + \\
\hline
\end{tabular}

a) Surface contact method ( $3 \mathrm{mg} / \mathrm{jar} / 10$ roaches).

b) Median lethal time, values are given as $\mathrm{X} \pm \mathrm{S}$.E. in $\mathrm{hr}$.

c) At $10^{-5} \mathrm{M}$ concentration of chemicals in $2 \mathrm{hr}$.

d) Symbol + means that dieldrin type nerve excitation was observed.

Table 13 Comparative toxicities of pyrethroids, parathion, chlordimeform and DDT to dieldrin susceptible (CSMA) and resistant (LPP) German cockroaches. ${ }^{a}$ )

\begin{tabular}{|c|c|c|c|c|c|}
\hline \multirow{2}{*}{ Chemicals } & \multirow{2}{*}{$\begin{array}{c}\text { Dose } \\
(\mu \mathrm{g} / \mathrm{jar})\end{array}$} & \multicolumn{2}{|c|}{$\mathrm{KT}_{50}(\min )^{\mathrm{b})}$} & \multirow{2}{*}{$\frac{\text { Resistance ratio }}{\text { LPP/CSMA }}$} & \multirow{2}{*}{$\begin{array}{l}\text { Dieldrind }^{d} \\
\text { type nerve } \\
\text { excitation }\end{array}$} \\
\hline & & CSMA strain & LPP strain & & \\
\hline Bioallethrin & 200 & $\begin{array}{c}8.0 \pm 2.3 \\
(26.5 \pm 1.6)^{c)}\end{array}$ & $\begin{array}{c}5.8 \pm 1.4 \\
\left.(26.8 \pm 2.0)^{c}\right)\end{array}$ & $\begin{array}{c}0.73 \pm 0.27 \\
(1.01 \pm 0.08)\end{array}$ & $-\left(10^{-7} \mathrm{M}\right)$ \\
\hline Permethrin & 150 & $\begin{array}{c}18.0 \pm 3.4 \\
(26.2 \pm 0.7)^{\mathrm{c})}\end{array}$ & $\begin{array}{c}17.4 \pm 3.4 \\
(22.8 \pm 1.0)^{\mathrm{c})}\end{array}$ & $\begin{array}{c}0.97 \pm 0.26 \\
(0.87 \pm 0.04)\end{array}$ & $-\left(10^{-7} \mathrm{M}\right)$ \\
\hline Fenvalerate & 150 & $\begin{array}{c}17.3 \pm 3.3 \\
(40.4 \pm 8.1)^{\mathrm{c})}\end{array}$ & $\begin{array}{c}14.9 \pm 2.9 \\
\left.(37.1 \pm 3.6)^{\mathrm{c}}\right)\end{array}$ & $\begin{array}{c}0.86 \pm 0.23 \\
(0.92 \pm 0.20)\end{array}$ & $-\left(10^{-7} \mathrm{M}\right)$ \\
\hline Cypermethrin & 100 & $\begin{array}{c}17.3 \pm 6.2 \\
\left.(37.5 \pm 3.4)^{\mathrm{c}}\right)\end{array}$ & $\begin{array}{c}19.6 \pm 6.5 \\
(36.2 \pm 3.3)^{c)}\end{array}$ & $\begin{array}{c}1.13 \pm 0.55 \\
(0.97 \pm 0.12)\end{array}$ & $-\left(10^{-7} \mathrm{M}\right)$ \\
\hline Deltamethrin & 20 & $\begin{array}{c}13.4 \pm 2.7 \\
(35.7 \pm 3.9)^{c)}\end{array}$ & $\begin{array}{c}9.7 \pm 4.5 \\
(33.5 \pm 8.2)^{\mathrm{c})}\end{array}$ & $\begin{array}{c}0.72 \pm 0.37 \\
\left.(0.94 \pm 0.25)^{\mathrm{c}}\right)\end{array}$ & $-\left(10^{-7} \mathrm{M}\right)$ \\
\hline Parathion & 1000 & $\begin{array}{l}65.9 \pm 4.3 \\
\left.(7.5 \pm 2.0)^{c}\right)\end{array}$ & $\begin{array}{l}58.9 \pm 2.1 \\
\left.(8.7 \pm 2.9)^{c}\right)\end{array}$ & $\begin{array}{c}0.89 \pm 0.07 \\
(1.17 \pm 0.50)\end{array}$ & $-\left(10^{-5} \mathrm{M}\right)$ \\
\hline Chlordimeform & 1000 & $126.4 \pm 19.2$ & $101.8 \pm 16.4$ & $0.81 \pm 0.18$ & $-\left(10^{-3} \mathrm{M}\right)$ \\
\hline DDT & 6000 & $638.8 \pm 107.0$ & $342.6 \pm 48.8$ & $0.54 \pm 0.12$ & $-\left(10^{-5} \mathrm{M}\right)$ \\
\hline
\end{tabular}

a) Surface contact method ( $\mu \mathrm{g} / \mathrm{jar} / 10$ roaches).

b) Median knockdown time, values are given as $\mathrm{X} \pm \mathrm{S}$.E. in $\min$.

c) $\mathrm{LT}_{50}$ values of the above chemicals (values are given as $\mathrm{X} \pm \mathrm{S}$.E. in $\mathrm{hr}$ ) are shown in parentheses.

d) Dieldrin type nerve excitation was not observed at the concentration shown in parentheses.

筋肉を放射性塩素イオン $\left({ }^{36} \mathrm{Cl}-\right)$ を含む昆虫用リンゲル 液に一定時間浸し，筇肉内に取り込まれた放射能を測定 する方法を用いて，各種薬剤による神経膜の $\mathrm{Cl}$ ーイオン 透過性の影響を調べた. 内部標準として ${ }^{3} \mathrm{H}$ 標識の mannitolを用い筋肉内に取り込をれた ${ }^{36} \mathrm{Cl}$ と ${ }^{3} \mathrm{H}$ とを 2 チャ ンネルの液体シンチレーションカウンターで同時に測定 した. ${ }^{3} \mathrm{H}$ を併用した理由は, リンゲル液の non specific
な筋肉表面への付着や筋肉内部への取り込みを知るため で, データの補正には必須である。

Milbemycin や avermectin は ${ }^{36} \mathrm{Cl}$ イイオンの取り込み を高めた (Table 15). ${ }^{36} \mathrm{Cl}$ イオンの取り込み量は薬剤 濃度, 処理時間に依存しており,これらの薬剤により specific な $\mathrm{Cl}$ イオンの筋肉内への取り込み (influx) が起こ ったことがわかる。この ${ }^{36} \mathrm{Cl}$ の取り込みの一部は PTX 
Table 14 Comparative toxicities of various chemicals to dieldrin susceptible (CSMA) and resistant (LPP) German cockroaches. ${ }^{a}$ )

\begin{tabular}{|c|c|c|c|c|c|}
\hline \multirow{2}{*}{ Chemicals } & \multirow{2}{*}{ Hour } & \multicolumn{2}{|c|}{$\mathrm{LD}_{50}{ }^{\mathrm{b})}(\mu \mathrm{g} /$ roach $)$} & \multirow{2}{*}{$\frac{\text { Resistance ratio }}{(\mathrm{LPP} / \mathrm{CSMA})}$} & \multirow{2}{*}{$\begin{array}{l}\text { Dieldring) } \\
\text { type nerve } \\
\text { excitation }\end{array}$} \\
\hline & & CSMA strain & LPP strain & & \\
\hline Mirex & 84 & $3.12 \pm 0.94$ & $2.85 \pm 0.95$ & $0.91 \pm 0.41$ & $-\left(10^{-4} \mathrm{M}\right)$ \\
\hline \multirow[t]{2}{*}{ Kepone } & 60 & $6.89 \pm 1.84$ & $14.78 \pm 3.86$ & $2.15 \pm 0.80$ & $\left.+\left(10^{-4} \mathrm{M}\right)^{\mathrm{h}}\right)$ \\
\hline & 84 & $5.08 \pm 0.83$ & $5.92 \pm 1.10$ & $1.17 \pm 0.29$ & \\
\hline \multirow[t]{2}{*}{ Toxaphene } & 24 & $2.46 \pm 0.40$ & $\left.>40^{\mathrm{d}}\right)$ & $>16.36$ & $+\left(10^{-5} \mathrm{M}\right)$ \\
\hline & 48 & $1.28 \pm 0.19$ & $\left.>40^{e}\right)$ & $>31.25$ & \\
\hline$\alpha-\mathrm{BHC}$ & 24 & $7.67 \pm 4.51$ & $>50^{f)}$ & $>6.51$ & $+\left(10^{-4} \mathrm{M}\right)$ \\
\hline$\gamma-\mathrm{BHC}$ & 24 & $0.23 \pm 0.07$ & $11.75 \pm 2.79$ & $50.87 \pm 19.70$ & $+\left(10^{-5} \mathrm{M}\right)$ \\
\hline 2,10-Dichlorobornane ${ }^{\mathrm{c}}$ ) & 24 & $16.90 \pm 7.20$ & $55.00 \pm 7.80$ & $3.25 \pm 1.46$ & \\
\hline Benzodiazepam ${ }^{\mathbf{c}}$ ) & 24 & $15.70 \pm 7.20$ & $20.90 \pm 6.50$ & $1.33 \pm 0.74$ & $-\left(10^{-4} \mathrm{M}\right)$ \\
\hline TETS $^{\mathbf{c}}$ & 24 & $0.32 \pm 0.05$ & $1.92 \pm 0.31$ & $6.00 \pm 1.35$ & $-\left(10^{-4} \mathrm{M}\right)$ \\
\hline$t$-Butyl bicyclic phosphate $\left.{ }^{c}\right)$ & 24 & $0.10 \pm 0.02$ & $1.46 \pm 0.38$ & $14.60 \pm 4.79$ & $+\left(10^{-4} \mathrm{M}\right)$ \\
\hline SQ-65396 ) & 72 & \multicolumn{2}{|c|}{ Not insecticidal at $30 \mu \mathrm{g}$} & & $-\left(10^{-4} \mathrm{M}\right)$ \\
\hline SQ-20009c) & 72 & \multicolumn{2}{|c|}{ Not insecticidal at $30 \mu \mathrm{g}$} & & $-\left(10^{-4} \mathrm{M}\right)$ \\
\hline
\end{tabular}

a) Topical application method (mirex, toxaphene and $\gamma$-BHC) and injection method ( $\alpha$-BHC 2,10dichlorobornane, benzodiazepam, TETS, $t$-butyl bicyclic phosphate, SQ-65396 and SQ-20009) were used.

b) Median lethal dose, values are given as $\mathrm{X} \pm \mathrm{S}$.E. in $\mu \mathrm{g}$.

c) Piperonyl butoxide $(10 \mu \mathrm{g} / \mathrm{roach})$ was applied $1 \mathrm{hr}$ before the treatment of the test chemicals.

d) No mortality at $40 \mu \mathrm{g}$.

e) $30 \%$ mortality at $40 \mu \mathrm{g}$.

f) No mortality at $50 \mu \mathrm{g}$.

g) Symbols + and - mean that dieldrin type nerve excitation was observed and not observed, respectively, at the concentration shown in parentheses.

h) The effect was weak and transient.

Table 15 Comparison of action of GABA, milbemycin, and avermectin on ${ }^{36} \mathrm{Cl}^{-}$uptake processes in the leg muscles of the American cockroach.

\begin{tabular}{lcc}
\hline \multicolumn{1}{c}{ Compounds } & $n$ & $\begin{array}{c}{ }^{36} \mathrm{Cl} \text { influx } \\
(\%)\end{array}$ \\
\hline Control & 8 & $100.00 \pm 4.32$ \\
Avermectin $\left(10^{-7} \mathrm{M}\right)$ & 8 & $115.87 \pm 7.95$ \\
Milbemycin $\left(10^{-7} \mathrm{M}\right)$ & 8 & $116.63 \pm 4.99$ \\
GABA $\left(10^{-3} \mathrm{M}\right)$ & 8 & $104.18 \pm 5.92$ \\
Avermectin $\left(10^{-7} \mathrm{M}\right)$ & & \\
$\quad+$ GABA $\left(10^{-3} \mathrm{M}\right)$ & 8 & $116.30 \pm 8.22$ \\
\hline
\end{tabular}

により阻害されたが, bicuculline ではほとんど阻害され なかった (Table 16). 一方, リンゲル液中の $\mathrm{Na}^{+}$全部 を，神経膜を通過しない第 4 級アンモニウムに置き換 え，同様の実験を行なったが，これら薬剤による ${ }^{36} \mathrm{Cl}$ イオン取り込みの増大は同様にみられた。したがって, これら薬剤による神経膜の $\mathrm{Cl}$-イオンに対する透過性の
Table 16 Antagonistic actions of picrotoxinin and bicuculline on avermectin-induced increase in ${ }^{36} \mathrm{Cl}-$ uptake by the cockroach leg muscles.

\begin{tabular}{|c|c|c|}
\hline Compounds & $n$ & $\begin{array}{l}{ }^{36} \mathrm{Cl}-\text { influx } \\
(\%)\end{array}$ \\
\hline Control & 8 & $100.00 \pm 4.32$ \\
\hline Avermectin $\left(10^{-7} \mathrm{M}\right)$ & 8 & $115.87 \pm 7.95$ \\
\hline $\begin{array}{l}\text { Avermectin }\left(10^{-7} \mathrm{M}\right) \\
\quad+\text { picrotoxinin }\left(1 \mathrm{C}^{-4} \mathrm{M}\right)\end{array}$ & 8 & $108.12 \pm 6.72$ \\
\hline $\begin{array}{l}\text { Avermectin }\left(10^{-7} \mathrm{M}\right) \\
\quad+\text { bicuculline } \\
\text { methiodide }\left(10^{-4} \mathrm{M}\right)\end{array}$ & 8 & $113.08 \pm 4.73$ \\
\hline
\end{tabular}

増大は $\mathrm{Na}^{+}$に依存せず, $\mathrm{Cl}^{-}$イオンに specific な現象で あることが明らかとなった。

\section{GABA, PTX, benzodiazepam 受容体}

ワモンゴキブリの中枢神経，筋肉には，GABA，PTX， benzodiazepam それぞれが高い親和性を示す部位が存在 しているが，これらの部位へのそれぞれの放射性リガン 
Table 17 Effect of avermectin on $\left[{ }^{3} \mathrm{H}\right]$ muscimol, $\left[{ }^{3} \mathrm{H}\right]$ benzodiazepam, and $\left[{ }^{3} \mathrm{H}\right]$ dihydropicrotoxinin binding.

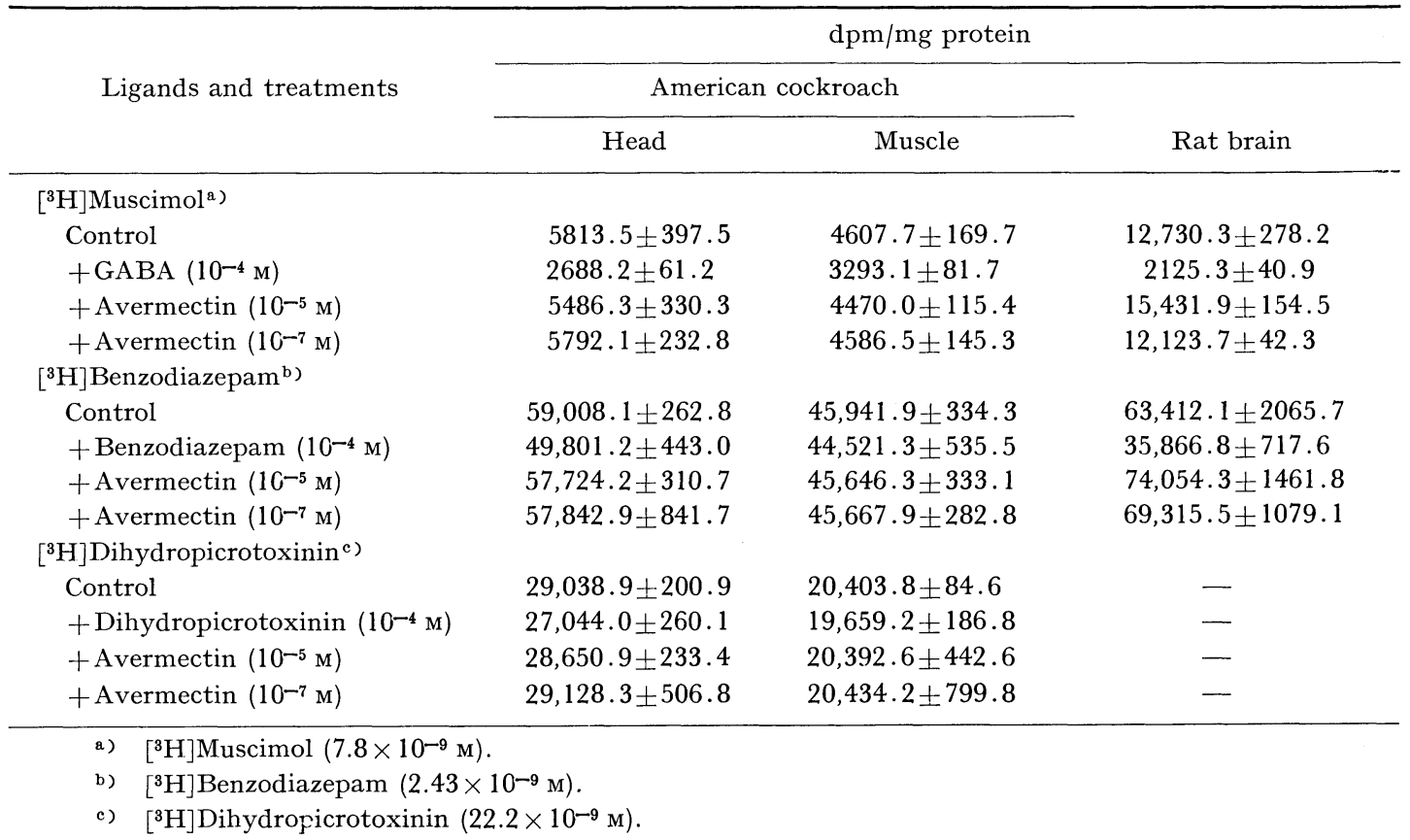

ドの結合には， avermectin は何ら影響を与えなかった (Table 17). ラット脳シナプトゾームでは, avermectin は GABA, benzodiazepam いずれの受容体に対してもと れぞれの放射性リガンドの結合の増大がみられ，昆虫， 哺乳動物間できわだった違いが認められた. Milbemycin でも同様の現象が認められた。

以上のことから, milbemycin や avermectin による神 経膜の $\mathrm{Cl}^{-}$イオンの透過性の増大は, $\mathrm{Cl}^{-}$イオンチャン ネルの開閉を司っている GABA 受容体や, benzodiazepam 受容体, PTX 受容体にこれら薬剤が作用しての結 果ではなく，別の部位に作用し直接 $\mathrm{Cl}$ イイオンチンネ ルを開の状態にすることによっていると解釈できる.

\section{おわりに}

すでに殺虫剂としては過去のものとなった $\gamma$ - BHC や cyclodiene が，どのような作用メカニズムで昆虫を興奮 させていたか, その扮よとの輪郭は明らかとなった。 一方新規な殺出用, あるいは駆虫薬として世に出てきた milbemycin や avermectin も， $\gamma$-BHC や cyclodiene と同 じ抑制性シナップスに作用していたが，その作用性はま ったく逆であることが明らかとなった.一見関連のまっ たくないようにみえる中毒症状が，実は同じ作用部位一
GABA-PTX-Cl- イオンチャンネルを介してのものであ ったわけである.これらの知見は，この抑制性シナップ ス理解の第一歩であって, 冒頭ふれたとおり, 理解しよ うとする部位に特異的に作用する薬剤がいったんわれわ れの手に入ると, その部位に関する理解は飛躍的に深ま るはずであり，その意味から本研究が今後の“GABA” 研究進展の一助になれば幸いである.

最後に, 本研究に従事する機会を与えてくださり, か つ終始懇篤なるご指導を賜わったミシガン州立大学教授 松村文夫先生, 京都大学名誉教授中島 稔先生に深く感 謝の意を表します. また，ミシガン州立大学において机 を並べ有益なるディスカッションによって種々啓発して くださった島根大学農学部尾添嘉久博士に心からお礼申 し上げます，終始貴重なご指導，ご助言を賜わった京都 大学教授藤田稔夫先生, 同教授栗原紀夫先生に心からお 礼を申し上げます. そして, 終始ご支援, ご助言をいた だきました三共株式会社高橋省吾氏, 石田三雄博士なら びに農薬研究所の皆様に深謝いたします。

\section{引用文 献}

1) 田中啓司：農薬誌 10, 555 (1985) 
2) A. A. Kadous, S. M. Ghiasuddin, F. Matsumura, J. G. Scott \& K. Tanaka: Pestic. Biochem. Physiol. 19, 157 (1983)

3) K. Tanaka \& F. Matsumura: "Membrane Receptors and Enzymes as Targets of Insecticidal Action," ed. by J. M. Clark \& F. Matsumura, Plenum Press, New York, p. 33, 1986

4) S. B. Soloway: Adv. Pest Control Res. 6, 85 (1965)

5) J. R. Busvine \& M. G. Townsend: Bull. Entomol. Res. 53, 763 (1963)

6) J. R. Busvine: Bull. Entomol. Res. 55, 271 (1964)

7) D. L. Shankland \& M. E. Schroeder: Pestic. Biochem. Physiol. 3, 77 (1973)

8) M. Uchida, T. Fujita, N. Kurihara \& M. Nakajima: "Pesticide and Venom Neurotoxicity," ed. by D. L. Shankland, R. M. Hollingworth \& T. Smyth, Jr., Plenum Press, New York, p. 133, 1978

9) K. Tanaka, J. G. Scott \& F. Matsumura: Pestic. Biochem. Physiol. 22, 117 (1984)

10) C. H. Jarboe, L. A. Porter \& R. T. Buckler: J. Med. Chem. 11, 729 (1968)

11) L. J. Mullins: Science 122, 118 (1955)

12) M. K. Ticku \& R. W. Olsen: Life Sci. 22, 1643 (1978)

13) L. J. Lawrence \& J. E. Casida: Science 221, 1399 (1983)

14) K. Tanaka, M. Nakajima \& N. Kurihara:
Pestic. Biochem. Physiol. 16, 149 (1981)

15) K. Tanaka, N. Kurihara \& M. Nakajima: Pestic. Biochem. Physiol. 6, 386 (1976)

16) F. Matsumura \& K. Tanaka: "Cellular and Molecular Neurotoxicology," ed. by T. Narahashi, Raven Press, New York, p. 225, 1984

17) L. C. Fritz, C. C. Wang \& A. Gorio: Proc. Natl. Acad. Sci. U.S.A. 76, 2062 (1979)

18) H. Mishima: "Pesticide Chemistry: Human Welfare and the Environment," ed. by J. Miyamoto \& P. C. Kearney, Vol. 2, Pergamon Press, Oxford, p. 129, 1983

19) R. A. Dybas: "Pesticide Chemistry: Human Welfare and the Environment," ed. by J. Miyamoto \& P. C. Kearney, Vol. 1, Pergamon Press, Oxford, p. 83, 1983

20) K. Tanaka \& F. Matsumura: Pestic. Biochem. Physiol. 24, 124 (1985)

21) K. G. Pearson \& C. R. Fourtner: Can. J. Zool. 51, 859 (1973)

22) K. Tanaka, A. Aoki \& F. Matsumura: in preparation 